\title{
PHYSIOLOGICAL QUALITY OF SEEDS OF Enterolobium contortisiliquum (VELL.) MORONG. STORED
}

\author{
QUALIDADE FISIOLÓGICA DE SEMENTES DE Enterolobium contortisiliquum \\ (VELL.) MORONG. ARMAZENADAS
}

\author{
Rosemere dos Santos SILVA; Edna Ursulino ALVES²; Flávio Ricardo da Silva CRUZ; \\ Luciana Rodrigues ARAÚJO ${ }^{4}$; Caroline Marques RODRIGUES ${ }^{5}$ \\ 1. Mestra em Agronomia pelo Programa de Pós-Graduação em Agronomia, Universidade Federal da Paraíba, Areia, PB, Brasil. \\ rosyufpbio@ @otmail.com; 2. Professora Associada, Departamento de Fitotecnia e Ciências Ambientas, Areia, PB, Brasil; 3. Doutor em \\ Agronomia pelo Programa de Pós-Graduação em Agronomia, Universidade Federal da Paraíba, Areia, PB, Brasil; 4. Doutora em \\ Agronomia pelo Programa de Pós-Graduação em Agronomia, Universidade Federal da Paraíba, Areia, PB, Brasil; 5. Engenheira \\ Agrônoma pela Universidade Federal da Paraíba - Unidade Acadêmica de Garanhuns.
}

\begin{abstract}
The species Enterolobium contortisiliquum (Vell.) Morong., (Fabaceae) is widely distributed in Brazil, commonly found in the Atlantic Forest domain. Despite its importance for the ecosystems, studies based on storage of E. contortisiliquum seeds are scarce. The objective of this work was to evaluate the physiological quality of seeds of Enterolobium contortisiliquum stored in different packages, environments and storage periods. The seeds were obtained from ripe fruits at the beginning of the natural dispersion in seven selected trees, located in the municipality of Areia Paraíba, between the months of November and December 2010 and then taken to the laboratory for analysis of Seeds of the Department of Plant Science and Environmental Agricultural Sciences Center of the Universidade Federal da Paraíba. A completely randomized design was used, with subdivided plots, being the major portion constituted by environments (lab, cold storage chamber, freezer and fridge), a sub-plot for the packages (kraft paper bag, cloth, aluminum, plastic (PP) and PET bottle) and the sub plot constituted by the storage periods (0, 30, 60, 90, 120, 150, 180, 210,240 and 270 days). For the evaluation of physiological quality was determined by water content, percentage of emergence, length and dry weight of shoots and roots. The packing of seeds of E. contortisiliquum can be made in polypropylene plastic bags (PP) and they can be stored under natural laboratory environment for 270 days with no decrease of seed vigor.
\end{abstract}

KEYWORDS: Forest species. Packing. Storage. Conservation. Viability.

\section{INTRODUCTION}

The species Enterolobium contortisiliquum (Vell.) Morong, in the family Fabaceae, subfamily Mimosoideae, popularly known as monkfish, monkey ears, monkeysoap, among others, is native forest formations, especially the Atlantic forest domain; however, has a wide distribution in the Brazilian territory (LORENZI, 2002). Due to the rapid initial growth is quite suitable for mixed plantations and reforestation of degraded areas (ARAÚJO; PAIVA SOBRINHO, 2011).

Similarly, to many other forest species, populations of E. contortisiliquum has been reduced, which reflects the predatory exploitation of the forests in which it naturally occurs. In face of the serious problems caused by the removal of the tree component of a given area, become essential measures which contribute to minimizing the problem. In this regard, the study of the optimum conditions of storage of seeds of forest species assists in determining the best conditions providing the maintenance of physiological quality, preserving the germinal power and ensuring viable seeds for seedling production over time (GUEDES et al., 2010).

The seed is a very important input in agriculture, constituting the first factor of the success or failure of any activity that it relies; by productive capabilities include all plants. In many species that reproduce by seeds, the same is the beginning and the end of the cycle of plants, because everything starts by germination and, after the formation of the plant all of your biological processes are invested for their perpetuation, namely, in the formation of new seeds (POPINIGIS, 1985). Other features of the seed, which worth mentioning are the ability to remain viable during storage and dispersibility, ensuring the perpetuation and dissemination of species over time (CARVALHO; NAKAGAWA, 2012).

Due to the serious problems caused by the removal of the tree component of a given area, become essential measures that will contribute to the minimization of the same. Storage is a practice of great importance for the control of physiological quality of seeds because it is responsible for maintaining the viability of same (AZEVEDO et al., 
2003). Forest seed store, the process of deterioration cannot be avoided; however, the correct storage can help you control your speed of deterioration (VIEIRA et al., 2001). Thus, factors such as relative humidity and temperature of the storage environment affect the quality of the seeds during storage (BORBA FILHO; PEREZ, 2009).

Depending on the environmental conditions and characteristics of the seed itself, deterioration can occur more quickly or slowly (TAKAHASHI et al., 2009), being necessary, for both, the correct choice of the environment and of the container that will be used for storage. In addition, the storage period interferes directly in the success of the practice, because the container used will influence in greater or lesser ease of exchange of water vapor between the seeds and the middle (MARCOS FILHO, 2015). The interaction between the storage period and different types of packaging should be carefully assessed, since each species may exhibit different behaviors under the same conditions (SOUZA et al., 2011). Therefore, the objective of this study was to evaluate the physiological quality of seeds of E. contortisiliquum stored.

\section{MATERIAL AND METHODS}

The work was conducted in a greenhouse seed Analysis Laboratory (LAS) of the Department of plant science and Environmental Sciences Agricultural Sciences Center of Federal University of Paraíba in Areia - PB.

The seeds of E. contortisiliquum were obtained from ripe fruits in seven selected trees located in the city of Areia, state of Paraíba, located in Northeast of Brazil, between the months of November and December 2010. The gathering was held at the beginning of the natural dispersion in the area of projection and cup directly in the trees with the aid of a trimmer and then taken to (LAS), where it forms opened manually using rubber mallets. After removal of impurities, the seeds were placed to dry in a greenhouse bench for five days, in order to reach the recommended storage humidity of $6 \%$. After seed processing the seeds were agitated in a cloth bag for a minute in order to be mixed and then packed in aluminum foil (seeds involved in two pieces of $20 \mathrm{~cm}$ of paper), Kraft paper bag, plastic bag type polypropylene (PP), cotton cloth bag and bottle pet (polyethylene terephthalate). The seeds were then stored in a natural laboratory environment $\left( \pm 25{ }^{\circ} \mathrm{C}\right.$ and $\left.74.5 \% \mathrm{RH}\right)$, cold storage chamber (-18 $\pm 2{ }^{\circ} \mathrm{C}$ and $\left.90 \% \mathrm{RH}\right)$ and in a domestic refrigerator $\left(6 \pm 2{ }^{\circ} \mathrm{C}\right.$ and $10-15 \%$ UR) net setting, being assessed as their physiological quality for 10 periods of storage $(0,30,60,90,120,150,180,210,240$ and 270 days). Before and after the intervals of 30 days order removed samples of each packaging and storage environment for determination and evaluation of physiological quality through the variables described below:

Water content - determined by the method of the greenhouse, at $105 \pm 3{ }^{\circ} \mathrm{C}$ during 24 hours (BRASIL, 2009), with four repetitions of 10 seeds. Emergence test - the test was carried out in a greenhouse, with four replicates of 25 seeds, which were scarified with sandpaper (60 grit) and treated with the fungicide Captan ${ }^{\circledR}$, using the dose of 240 $\mathrm{g} / 100 \mathrm{~kg}$ of seeds, then sown in trays of polyethylene with dimensions of $47 \times 33 \times 7 \mathrm{~cm}$, corresponding to the length, width and depth, respectively, containing sand washed and sterilized in an autoclave with daily irrigations for maintaining the humidity of the substrate. The counts were performed daily, from $4^{\circ}$ to $14^{\circ}$ day after the beginning of the test, considering how seedlings emerged those with $80 \%$ of the cotyledons above the substrate, and the results expressed in percentage.

Shoot and root length of seedlings - At the end of the emergence test, the normal seedlings of each repetition were selected and with the aid of a ruler graduated in centimeters, the shoot and root length were measured, the results were expressed in centimeters $(\mathrm{cm})$.

Dry weight of shoot and roots of seedlingsAfter removal of the cotyledons of normal seedlings for each repetition, the shoots and roots of the seedlings were placed separately in paper bags kraft type and taken to the lab stove at $80{ }^{\circ} \mathrm{C}$ until constant weight ( 24 hours), then weighted in an analytical scale, with an accuracy of $0.001 \mathrm{~g}$, the results were expressed in grams (g) (NAKAGAWA, 1999).

Experimental design and statistical analysisThe treatments were arranged in a completely randomized design scheme in subdivided portions, being the major portion constituted by environments, the sub-plot for the packaging and the subplot constituted by the storage periods. The data were submitted to analysis of variance by the $F$ test $(\mathrm{p} \leq 0.05)$ and polynomial regression, and the linear and quadratic models were evaluated, the models with highest significance degree and coefficient of determination $\left(R^{2} \geq 0.5\right)$ were chosen, the software SISVAR (FERREIRA, 2007) was used. 


\section{RESULTS AND DISCUSSION}

The paper bags under laboratory environment, and, cloth and aluminum foil in the refrigerator, and aluminum foil in the cold chamber were adjusted to the quadratic model of regression (Figure 1). In the other package there was no significant variation, in which the seeds remained with water percentage close to the initial until 270 days of storage, which means ranged from 6 to $7.18 \%$. This behavior may be related to the physical barrier conferred by the resistant and impermeable tegument of the seeds, preventing the movement of water and gas exchanges (AQUINO et al., 2009). This result corroborates the accounts of Bradbeer
SILVA, R. S. et al.

(1988), when he mentioned that most orthodox seed water content is around 5 to $20 \%$ based on their fresh matter.

The water content in the paper packaging tended to increase throughout the harvest in the natural laboratory environment. In the cloth and aluminum package there was a decrease with a subsequent increase in water content after 163 and 164 days of storage, respectively. Regarding the cold chamber environment, it was observed that for the seeds kept in aluminum package there was a decrease in the water content up to 90 days, with subsequent increase, with an accentuated increase as it reached 270 days.
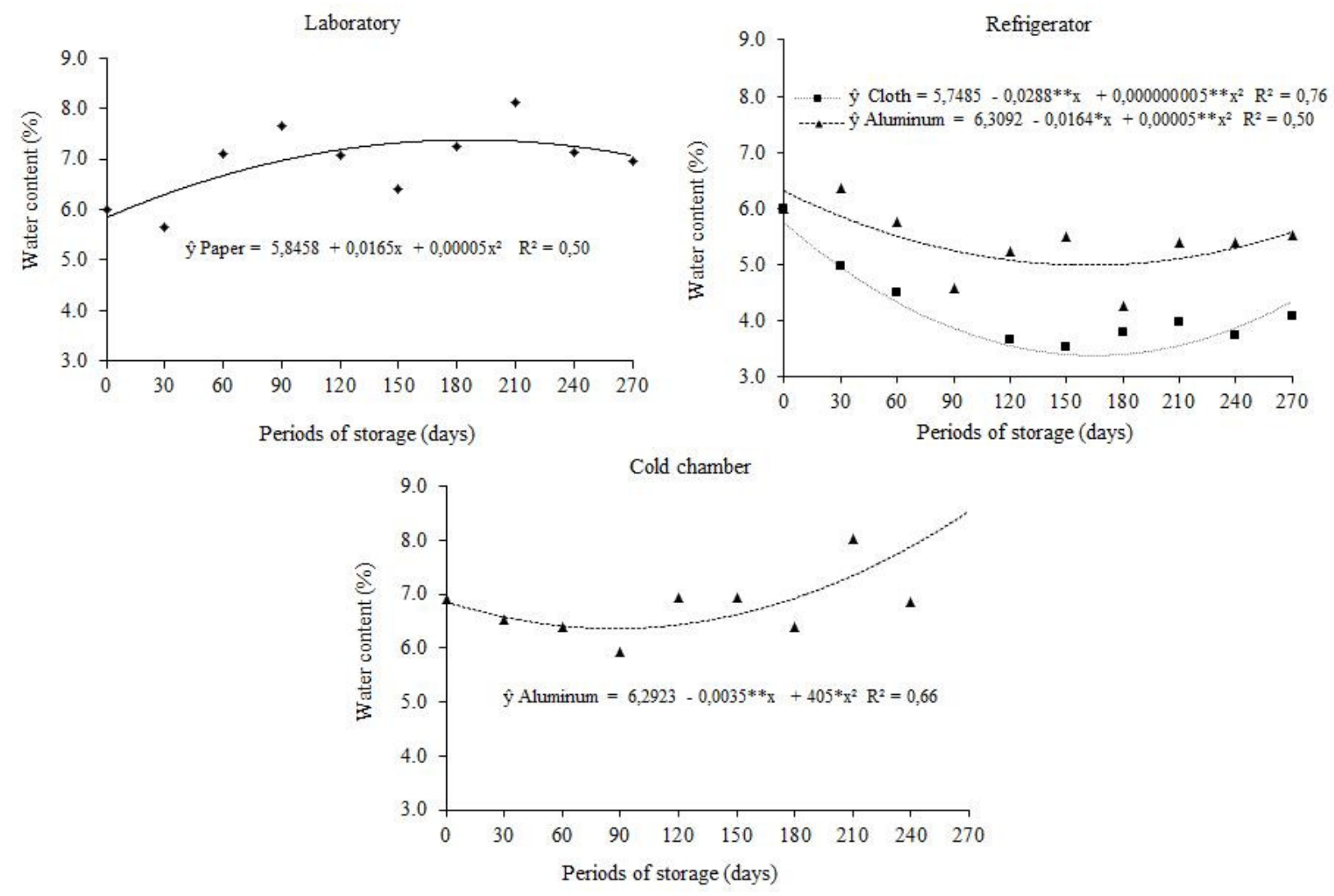

Figure 1. Water content of seeds of E. contortisiliquum stored in different environments and packages.

No significant difference was observed for the percentage of emergence of E. contortisiliquum seedlings (Figure 2), in the packages evaluated when the seeds were stored under natural laboratory and cold storage chamber conditions. In the refrigerator, the seeds packed in paper bags reached a minimum of $71 \%$ at 208 days of storage and the seeds packed in the tissue bag obtained a percentage of emergence of $79 \%$ at 164 days of storage.

In the freezer (Figure 2) data was adjusted to the quadratic function in aluminum packages and
PET bottles. The aluminum package better preserved the seeds of E. contortisilquum until 96 days, obtaining $86 \%$ of emergence, in the following periods a quadratic reduction was observed. This increase in the percentage of seedling emergence during storage may be related to the increase of seed dormancy (CATUNDA et al., 2003).

For the seeds stored in PET bottles, there was a gradual reduction, obtaining maximum values of $87 \%$ at 27 days of storage. The reduction in seedling emergence may be related to small 
fluctuations in water level that are sufficient to promote higher respiratory rates, which should increase seed reserves consumption during respiration and accelerate deterioration (DELOUCHE, 2002; LAMARCA, 2009;

Refrigerator

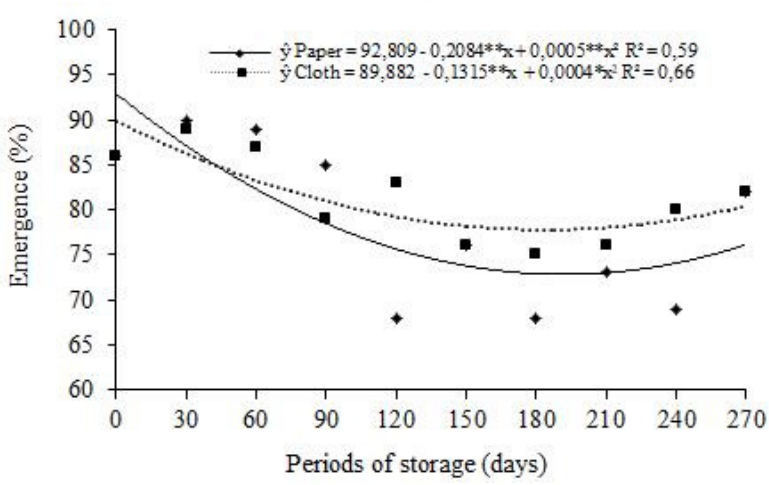

CARVALHO e NAKAGAWA, 2012). In catanduva seeds (Piptadenia moniliformis Benth.), There was also a decrease in the emergence in all the packages studied (BENEDITO et al., 2011).

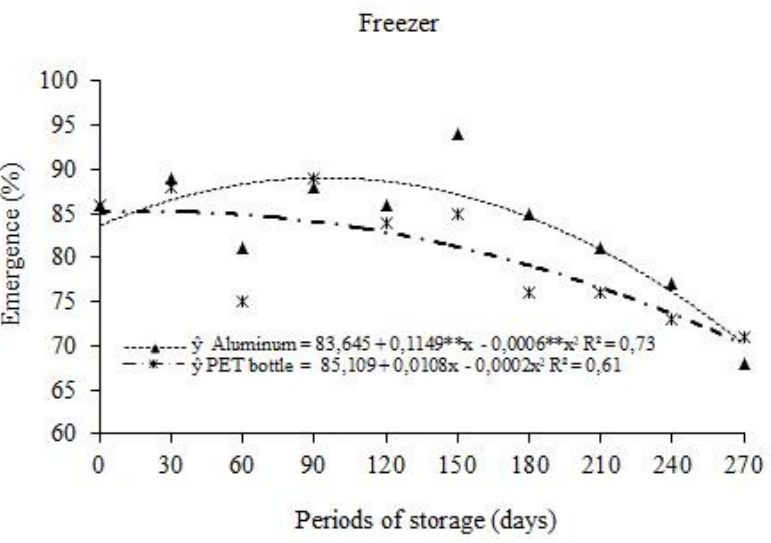

Figure 2. Emergence (\%) of E. contortisiliquum from stored seeds in different environments and packaging.

In relation to the results obtained for the effect based on seedlings development (Figure 3) the highest root length $(12.0 \mathrm{~cm})$ occurred in the initial periods for the seeds stored in tissue bag and conditioned in the natural laboratory environment, but with an accentuated decrease in these conditions of storage for other periods, obtaining a lower average of approximately $4.0 \mathrm{~cm}$ at 270 days of storage.

The seed vigor of E. contortisiliquum stored in the refrigerator and in the paper bag and PET bottles were also affected over time, which showed a quadratic reduction, the lowest values were observed at 184 and 169 days of storage, respectively.

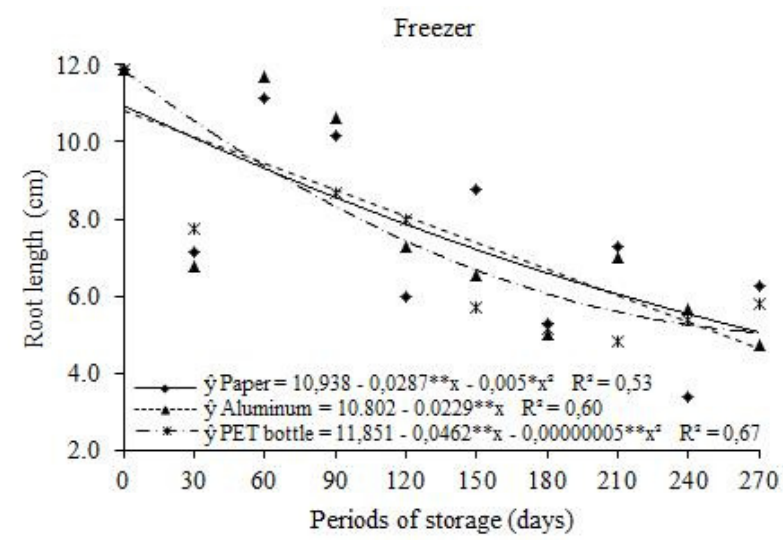

In the freezer the seeds packed with aluminum foil obtained a linear reduction in root length, when packed in a paper bag and PET bottle the reduction was quadratic, with minimum values at 264 and 259 days. In cold storage chamber, seeds packed in aluminum foil and plastic bags also showed an accentuated decrease throughout the storage period. In studies carried out with seeds of Erythrina velutina Willd. stored in different environments for 225 days, Silva et al. (2011) obtained higher root length at 81 days of storage, with mean values of $11.8 \mathrm{~cm}$ in laboratory environment.

Figure 3. Root length of seedlings of E. contortisiliquum from stored seeds in different environments and packaging.

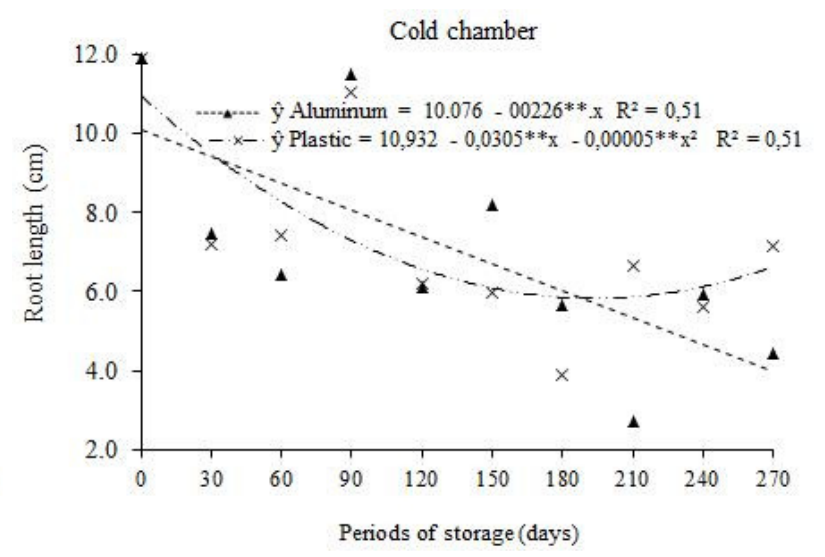


Figure 4 shows a critical point in the reduction of vigor in all storage environments, followed by a resumption of dry matter increase of the roots in those packages that were significant. Thus, aluminum and PET bottles in natural laboratory environments have their lowest value for dry matter of the roots at 150 and 125 days of storage, respectively. In the refrigerator, all packages were adjusted to the quadratic model of regression with lowest vigor reached at 125 days. In freezer, only the seeds packed in tissue bag, aluminum foil and PET bottle obtained quadratic

Freezer
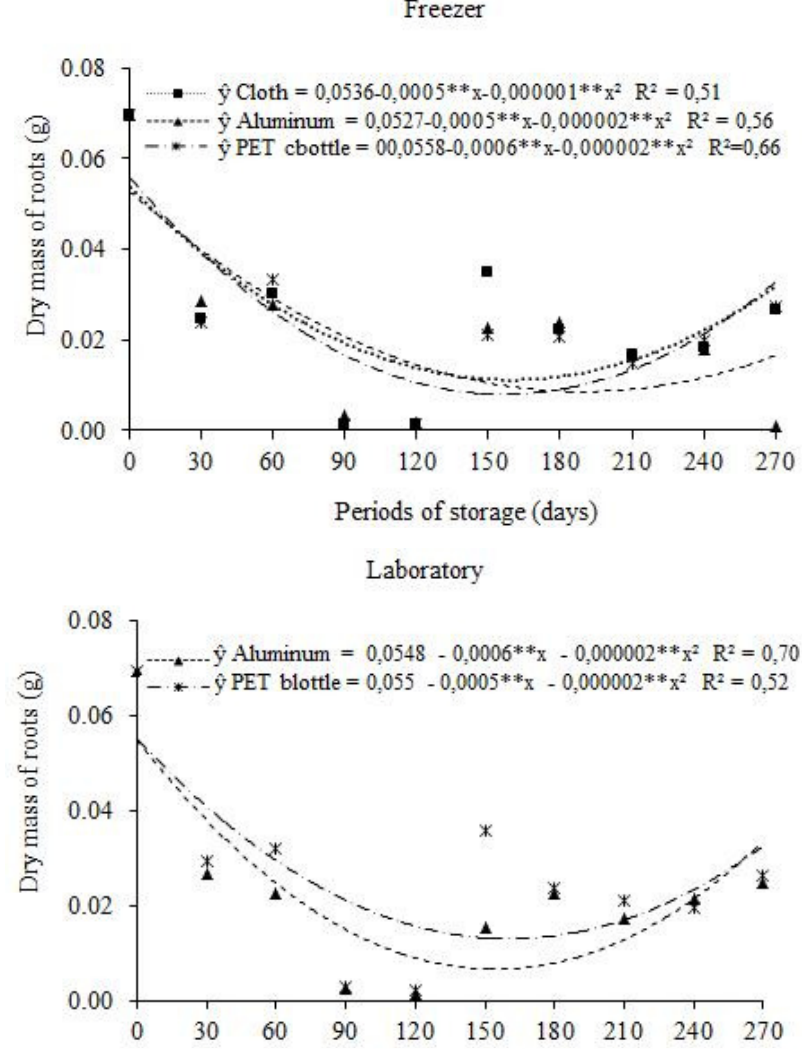

SILVA, R. S. et al.

reduction in fresh matter of roots. The same tendency can also be verified for the cold chamber storage data and in the aluminum packages with lowest value at 125 days of storage.

When studying the best environmental conditions and packages for seed storage of Machaerium stipitatum (DC.) Vog, Medeiros and Zanon (2000) verified that the seeds packed in plastic bags and in cold storage chamber environment remained viable for a longer period of time, which did not occur for paper bag and natural laboratory environment storage.
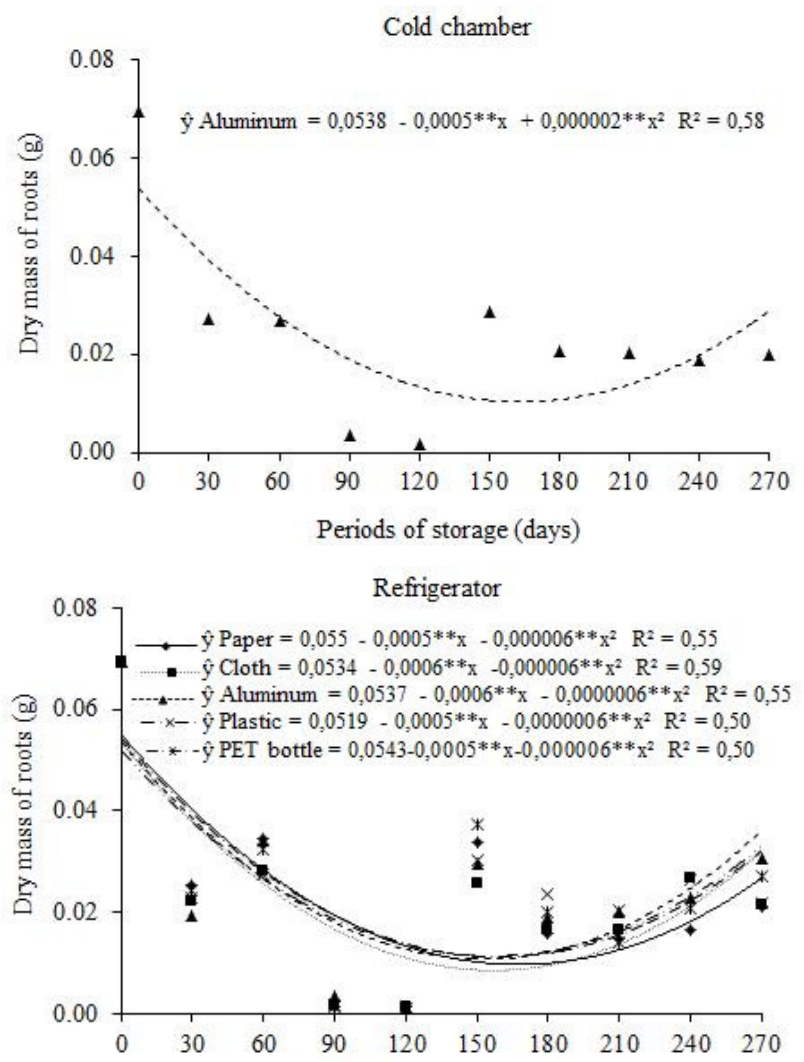

Figure 4. Dry matter of roots of E. contortisiliquum seedlings from seeds stored in different environments and packages.

The shoot dry matter content of $E$. contortisliquum (Figure 5) from seeds packed in aluminum foil and PET bottles in the natural laboratory environment were adjusted to the quadratic regression model, and it is possible to estimate that at 163 days of storage occurred the lowest values of 0.047 and $0.049 \mathrm{~g}$, respectively. The paper bag packaging was inefficient in maintaining the vigor with the lowest value of 0.045 $\mathrm{g}$ at 175 days of storage in the refrigerated environment.

It can be seen on Figure 5 for the freezer environment that the tissue bag and the PET bottle data were adjusted to the quadratic regression model in which the lowest values were observed at 183 days of storage. In the cold storage chamber environment, the paper bag promoted the same behavior in the conservation of E. contortisliquum seeds, which influenced the vigor of the seeds, the dry matter content decreased up to 108 days. Both, the shoot and root dry matter of the seedling of Apeiba tibourbou Aubl. stored in different packages and environments decreased up to 180 days (MATOS et al., 2008). 

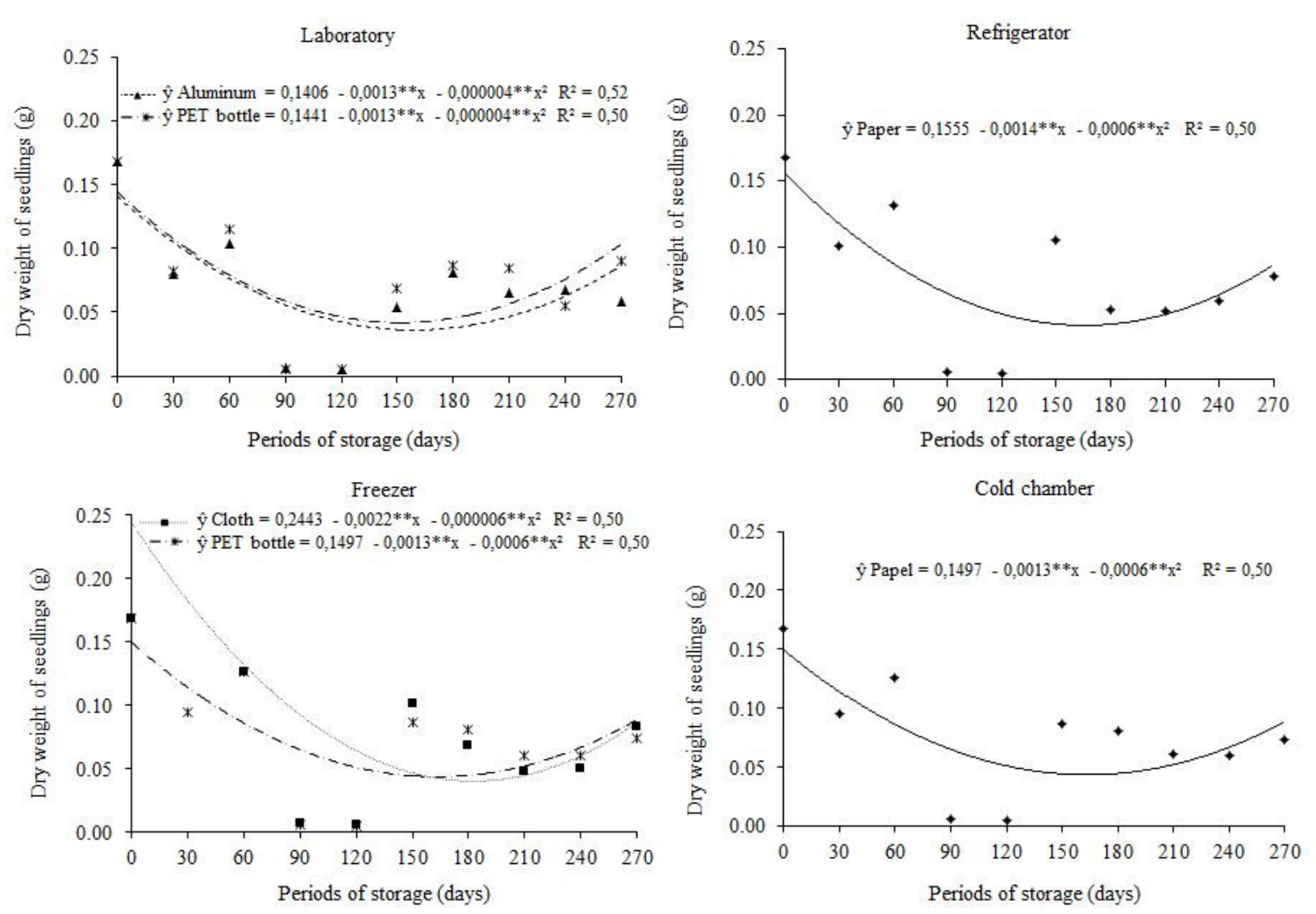

Figure 5. Dry weight of seedlings of E. contortisiliquum stored in different environments and packaging.

\section{CONCLUSIONS}

The packages of paper, tissue and aluminum in laboratory environment, refrigerator and cold storage chamber environments do not maintain the water content of Enterolobium contortisiliquum seeds;
The vigor of E. contortisilquum seeds is reduced throughout the storage period;

The freezer environment and the use of aluminum foil for packaging maintain the physiological quality of E. contortisiliquum seeds during 96 days of storage;

RESUMO: A espécie Enterolobium contortisiliquum (Vell.) Morong., (Fabaceae) tem ampla ocorrência no Brasil, especialmente no domínio de Mata Atlântica. Apesar de sua importância na dinâmica dos ecossistemas, os estudos sobre o armazenamento de suas sementes são escassos. Dessa forma, o objetivo do trabalho foi avaliar a qualidade fisiológica de sementes de Enterolobium contortisiliquum armazenadas em diferentes embalagens, ambientes e períodos de armazenamento. As sementes foram obtidas de frutos maduros no inicio da dispersão natural em sete árvores matrizes localizadas no município de Areia - PB, entre os meses de novembro e dezembro de 2010 e, em seguida, levados ao Laboratório de Análise de Sementes do Departamento de Fitotecnia e Ciências Ambientais do Centro de Ciências Agrárias da Universidade Federal da Paraíba. O delineamento foi inteiramente ao acaso em parcela subsubdividida, sendo a parcela principal constituída pelos ambientes (laboratório, câmara fria, freezer e geladeira), a subparcela pelas embalagens (papel kraft, pano, alumínio, plástico (PP) e garrafa PET) e a subsubparcela constituída pelos períodos de armazenamento (0, 30, $60,90,120,150,180,210,240$ e 270 dias). Para avaliação da qualidade fisiológica determinou-se o teor de água, porcentagem de emergência, comprimento e massa seca de parte aérea e raízes. As sementes de E. contortisiliquum podem ser acondicionadas em embalagem de saco de plástico de polipropileno (PP) e armazenadas em ambiente natural de laboratório durante 270 dias sem redução no vigor.

PALAVRAS-CHAVE: Espécie florestal. Embalagem. Conservação. Viabilidade. 


\section{REFERENCES}

AQUINO, A. M. A. G.; RIBEIRO, M. C. C.; PAULA, Y. C. M.; BENEDITO, C. P. Superação de dormência em sementes de orelha-de-negro (Enterolobium contortisiliquum (Vell.) Morang.). Revista Verde, Mossoró, v. 4, n. 1, p. 69-75, 2009. http://www.gvaa.com.br/revista/index.php/RVADS/article/view/151.

ARAUJO, A. P.; PAIVA SOBRINHO, S. Germinação e produção de mudas de tamboril (Enterolobium Contortisiliquum (Vell.) Morong) em diferentes substratos. Revista Árvore, Viçosa, v. 35, n. 3, p. 581-588, 2011. ISSN 0100-6762. http://dx.doi.org/10.1590/S0100-67622011000400001.

AZEVEDO, M. R. Q. A.; GOUVEIA, J. P. G.; TROVÃO, D. M. M.; QUEIROGA, V. P. Influência das embalagens e condições de armazenamento no vigor de sementes de gergelim. Revista Brasileira de Engenharia Agrícola e Ambiental, Campina Grande, v. 7, n. 3, p. 519-524, 2003. http://dx.doi.org/10.1590/S1415-43662003000300019.

BENEDITO, C. P.; RIBEIRO, M. C. C.; TORRES, S. B.; CAMACHO, R. G. V.; SOARES, A. N. R.; GUIMARÃES, L. M. S. Armazenamento de sementes de catanduva (Piptadenia moniliformis Benth.) em diferentes ambientes e embalagens. Revista Brasileira de Sementes, Lavras, v. 33, n. 1, p. 28-37, 2011. http://dx.doi.org/10.1590/S0101-31222011000100003.

BORBA FILHO, A. B.; PEREZ, S. C. J. G. A. Armazenamento de sementes de ipê-branco e ipê-roxo em diferentes embalagens e ambientes. Revista Brasileira de Sementes, Londrina, v. 31, n. 1, p. 259-269, 2009. http://dx.doi.org/10.1590/S0101-31222009000100029.

BRADBEER, J. W. Seed dormancy and germinatio. Glasgow: Blackie Son, 1988. 146 p.

BRASIL. Ministério da Agricultura, Pecuária e Abastecimento. Regras para análise de sementes. Secretaria de Defesa Agropecuária. Brasília, DF: MAPA/ACS, 2009. 395 p.

BORBA FILHO, A. B.; PEREZ, S. C. J. G. A. Armazenamento de sementes de ipê-branco e ipê-roxo em diferentes embalagens e ambientes. Revista Brasileira de Sementes, Londrina, v. 31, n. 1, p. 259-269, 2009. http://dx.doi.org/10.1590/S0101-31222009000100029.

CARVALHO, N. M.; NAKAGAWA, J. Sementes: ciência, tecnologia e produção. 5.ed. Jaboticabal: FUNEP, 2012. 590 p.

CATUNDA, P. H. A.; VIEIRA, H. D.; SILVA, R. F.; POSSE, S. C. P. Influência do teor de água, da embalagem e das condições de armazenamento na qualidade de sementes de maracujá amarelo. Revista Brasileira de Sementes, Pelotas, v. 25, n. 1, p. 65-71, 2003. http://dx.doi.org/10.1590/S010131222003000100011.

DELOUCHE, J. C. Germinação, deterioração e vigor da semente. Seed News, n.6, p.1-7, 2002.

FERREIRA, D. F. Sisvar 5.0: sistema de análises estatísticas. Lavras: UFLA, 2007.

GUEDES R. S.; ALVES, E. U.; GONÇALVES, E. P.; VIANA, J. S.; FRANÇA, P. R. C.; SANTOS, S. S. Qualidade fisiológica de sementes armazenadas de Amburana cearensis (Allemão) A.C. Smith. Semina: Ciências Agrárias, Londrina, v. 31, n. 2, p. 331-342, 2010. http://dx.doi.org/10.5433/16790359.2010v31n2p331.

LAMARCA, E. V. Taxas respiratórias e velocidade de deterioração de sementes de Caesalpinia echinata Lam. em função de variações hídricas e térmicas. 2009. 98 f. Dissertação (Mestrado em Biodiversidade Vegetal e Meio Ambiente) - Instituto de Botânica da Secretaria de Estado do Meio Ambiente, São Paulo-SP. arquivos.ambiente.sp.gov.br/pgibt/2013/09/Edmir_Lamarca_MS.pdf. 
LORENZI, H. Árvores brasileiras: manual de identificação e cultivo de plantas arbóreas do Brasil. 2.ed. Instituto Plantarum, Nova Odessa, São Paulo, 2002. 384 p.

MAGUIRE, J. D. Speed of germination aid in selection and evaluation for seedling emergence and vigor. Crop Science, Madison, v. 2, n. 2, p. 176-177, 1962.

MARCOS FILHO, J. M. Fisiologia de sementes de plantas cultivadas. Piracicaba: FEALQ, 2015. 495 p.

MATOS, V. P.; SOUSA, E. G. B.; FERREIRA, R. L. C.; SENA, H. M.; SALES, A. G. F. Efeito do tipo de embalagem e do ambiente de armazenamento sobre a germinação e o vigor das sementes de Apeiba tibourbou Aubl. Revista Árvore, Viçosa, v. 32, n. 4, p. 617-625, 2008. http://dx.doi.org/10.1590/S010067622008000400002 .

MEDEIROS, A. C. S.; ZANON, A. Armazenamento de sementes de sapuva (Machaerium stipitatum). Boletim de Pesquisa Florestal, Colombo, n. 40, p. 57-66, 2000. http://ainfo.cnptia.embrapa.br/digital/bitstream/CNPF2009-09/3017/1/medeiros.pdf.

NAKAGAWA, J. Testes de vigor baseados no desempenho das plântulas. In: KRZYZANOSKI, F.C.; VIEIRA, R. D.; FRANÇA NETO, J. B. (Ed.). Vigor de sementes: conceitos e testes. Londrina: ABRATES, 1999. p. 2.1-2.24.

POPINIGIS, F. Fisiologia da semente, Brasília: AGIPLAN, 1985. 289 p.

SILVA, K. B.; ALVES, E. U.; GONÇALVES, E. P.; BRUNO, R. L. A.; FRANÇA, P. R. C. Armazenamento de sementes de Erythrina velutina Willd. Revista Árvore, Viçosa, v. 35, n. 4, p. 809-816, 2011. http://dx.doi.org/10.1590/S0100-67622011000500006.

SOUZA, V. C.; ANDRADE, L. A.; CRUZ, F. R. S.; FABRICANTE, J. R.; OLIVEIRA, L. S. B. Conservação de sementes de marizeiro Geoffroea spinosa Jacq. utilizando diferentes embalagens e ambientes. Ciência Florestal, Santa Maria, v. 21, n. 1, p. 93-102, 2011. http://dx.doi.org/10.5902/198050982751.

TAKAHASHI, L. S. A. T.; SOUZA, J. R. P.; YOSHIDA, A. E.; ROCHA, J. N. Condições de armazenamento e tempo de embebição na germinação de sementes de erva-doce (Pimpinella anissum L.). Revista Brasileira de Plantas Medicinais, Botucatu, v. 11, n. 1, p. 1-6, 2009. http://dx.doi.org/10.5902/198050982751.

VIEIRA, A. H.; MARTINS, E. P.; PEQUENO, P. L. L. P.; LOCATELLI, M.; SOUZA, M. G. Técnicas de produção de sementes florestais. Porto Velho: EMBRAPA, CT 205, 2001. p. 1-4.

ainfo.cnptia.embrapa.br/digital/bitstream/item/24812/1/Cot-205.pdf. 